\title{
Catalytic B-N Dehydrogenation Using Frustrated Lewis Pairs: Evidence for a Chain-Growth Coupling Mechanism
}

\author{
Zhenbo Mo, Arnab Rit, Jesús Campos, Eugene L. Kolychev, and Simon Aldridge* \\ Inorganic Chemistry Laboratory, Department of Chemistry, University of Oxford, South Parks Road, Oxford OX1 3QR, United \\ Kingdom
}

Supporting Information

ABSTRACT: The catalytic dehydrogenation of ammoniaand amine-boranes by a dimethylxanthene-derived frustrated Lewis pair is described. Turnover is facilitated on a thermodynamic basis by the ready release of $\mathrm{H}_{2}$ from the weakly basic $\mathrm{PPh}_{2}$-containing system. In situ $\mathrm{NMR}$ studies and the isolation of intermediates from stoichiometric reactions support a mechanism initiated by $\mathrm{B}-\mathrm{H}$ activation, followed by end-growth BN coupling involving the terminal $\mathrm{NH}$ bond of the bound $\mathrm{BN}$ fragment and a $\mathrm{BH}$ bond of the incoming borane monomer.

$\mathrm{D}$ ehydrocoupling represents a powerful synthetic protocol for the construction of both homo- and heteronuclear E-E bonds in molecular and materials science. ${ }^{1}$ Among such processes, the formation of $\mathrm{B}-\mathrm{N}$ bonds, e.g., from ammoniaborane $\left(\mathrm{AB}, \mathrm{H}_{3} \mathrm{~B} \cdot \mathrm{NH}_{3}\right)$ or related amine-boranes $\left(\mathrm{H}_{3} \mathrm{~B} \cdot \mathrm{NH}_{2} \mathrm{R}\right)$, has been the subject of significant research effort, reflecting potential applications in hydrogen storage technologies and the synthesis of novel polymeric materials. ${ }^{2}$ While $\mathrm{B}-\mathrm{N}$ coupling can be effected thermally in some cases, reflecting the complementary polarities of $\mathrm{B}-\mathrm{H}$ and $\mathrm{N}-\mathrm{H}$ bonds, ${ }^{3}$ catalytic approaches have also been investigated with a view to enhancing the rate of $\mathrm{H}_{2}$ release and/or controlling the nature of the dehydrocoupled product(s). ${ }^{4}$ Metal complexes (from all parts of the Periodic Table) feature prominently among the most active catalyst systems reported to date, but other approaches, including the use of ionic liquids and Brønsted and Lewis acids/bases, have also been developed. $^{5-9}$

Frustrated Lewis pairs (FLPs), although described conceptually as far back as $1942,{ }^{10}$ emerged as a new paradigm for small molecule capture and activation following a landmark report by Stephan et al. in 2006. ${ }^{11,12}$ The ability of such systems (archetypally based on sterically shrouded tertiary phosphine and fluoroarylborane units) to activate strong nonpolar bonds, such as that in $\mathrm{H}_{2}$, has been exploited in "metal-free" catalysis. ${ }^{13}$ Prominent among such processes is FLP-catalyzed hydrogenation chemistry, ${ }^{13}$ which relies on the ability of the phosphonium hydroborate derived from heterolytic $\mathrm{H}_{2}$ cleavage to transfer $\mathrm{H}^{+} / \mathrm{H}^{-}$to unsaturated substrates such as imines. By contrast, FLP systems capable of effecting turnover in dehydrogenation chemistry are very rare indeed. ${ }^{9,14}$ In part this is due to the fact that in the absence of a suitable coreagent to act as a hydrogen acceptor (or the application of elevated temperature/ vacuum), the spontaneous loss of $\mathrm{H}_{2}$ in the reverse sense is often thermodynamically unfavorable. ${ }^{15,16}$ As a consequence, the evolution of $\mathrm{H}_{2}$ leads to rapid, irreversible sequestering of the FLP and prevents turnover.

In recent work we have developed single component FLPs based on a dimethylxanthene backbone that possess a $\mathrm{P} \cdots \mathrm{B}$ separation (4.2-4.5 $\AA$ ) preorganized for the facile uptake of $\mathrm{H}_{2}$. Moreover, by varying the cumulative Lewis acid/base strength of phosphine and borane components, a system can be designed (1; Scheme 1) which cleaves $\mathrm{H}_{2}$ to give an equilibrium mixture of free

Scheme 1. Synthesis and $\mathrm{H}_{2}$ Activation by DimethylxantheneBased FLPs 1-3

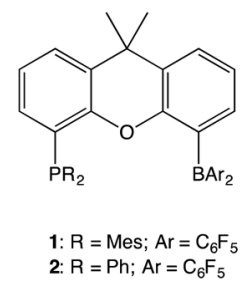

3: $\mathrm{R}=\mathrm{Ph} ; \mathrm{Ar}=$ Mes

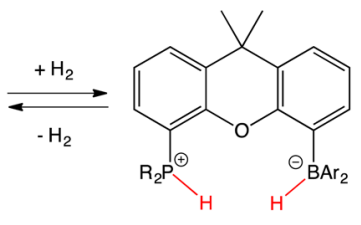

1-(H) $2: \mathrm{R}=\mathrm{Mes} ; \mathrm{Ar}=\mathrm{C}_{6} \mathrm{~F}_{5}$ 2-(H) $\mathrm{R}: \mathrm{R}=\mathrm{Ph} ; \mathrm{Ar}=\mathrm{C}_{6} \mathrm{~F}_{5}$

FLP and zwitterionic 1- $(\mathrm{H})_{2}$ in solution at room temperature. ${ }^{16}$ With this reversibility in mind, we hypothesized that $\mathbf{1}$ and related systems might be competent for the catalytic dehydrocoupling of $\mathrm{AB}$ and related substrates. As such, a new area of catalytic endeavor might be opened up to mediation by a metal-free FLP approach. $^{9}$

The phosphonium borohydride 1- $(\mathrm{H})_{2}$ derived from $\mathrm{PMes}_{2} /$ $\mathrm{B}\left(\mathrm{C}_{6} \mathrm{~F}_{5}\right)_{2}$ functionalized $\mathbf{1}$ has been shown to exist in equilibrium with the "free" FLP and dihydrogen at $295 \mathrm{~K}(\sim 20: 1 \text { 1-(H) })_{2}: 1$ mixture in bromobenzene; Scheme 1). ${ }^{16}$ Targeting applications in dehydrogenation chemistry, the related $\mathrm{PPh}_{2}$ variants 2 and 3 were targeted, reasoning that the incorporation of weaker Lewis acid/base components should lead to more favorable thermodynamics for $\mathrm{H}_{2}$ loss. ${ }^{17}$ These systems can be synthesized from 4,5dibromo-9,9-dimethylxanthene using a similar approach to that employed for $1,{ }^{16}$ and both 2 and 3 can be shown crystallographically to constitute a FLP (see SI). As expected, the uptake of $\mathrm{H}_{2}$ in each case is less thermodynamically favorable than that by $\mathbf{1}$ : in the case of $\mathbf{2}$, only $5 \%$ conversion to $2-(\mathrm{H})_{2}$ is observed spectroscopically upon exposure to $\mathrm{H}_{2}$ at 4 atm pressure at $295 \mathrm{~K}$. We were unable to obtain any evidence for the formation of 3$(\mathrm{H})_{2}$, presumably due to the much weaker Lewis acidity of the $-\mathrm{BMes}_{2}$ function. For 2 , the values of $\Delta H^{\mathrm{o}}$ and $\Delta S^{\mathrm{o}}$ obtained by

Received: February 1, 2016

Published: February 26, 2016 
monitoring the response of the equilibrium constant to temperature $\left(34 \mathrm{~kJ} \mathrm{~mol}^{-1}\right.$ and $\left.138 \mathrm{~J} \mathrm{~mol}^{-1} \mathrm{~K}^{-1}\right)$ can be compared to values of $38 \mathrm{~kJ} \mathrm{~mol}^{-1}$ and $102 \mathrm{~J} \mathrm{~mol}^{-1} \mathrm{~K}^{-1}$ obtained for the corresponding release of $\mathrm{H}_{2}$ by $1-(\mathrm{H})_{2}$.

Given the relative ease of $\mathrm{H}_{2}$ loss from 2-(H) , we set out to investigate the use of $\mathbf{2}$ as a catalyst in dehydrogenation chemistry. Accordingly, $\mathbf{2}$ is found to catalyze the dehydrocoupling of methylamine- and ammonia-borane to the corresponding $\mathrm{Me}$ - or $\mathrm{H}$-substituted borazine and of dimethylamine-borane to $\mathrm{H}_{2} \mathrm{~B}(\mu$ $\left.\mathrm{NMe}_{2}\right)_{2} \mathrm{BH}_{2}$ at $328 \mathrm{~K}$ and $1 \mathrm{~mol} \%$ catalyst loading (Scheme 2).

Scheme 2. Catalytic Dehydrogenation of Amine and

Ammonia-Boranes by 2

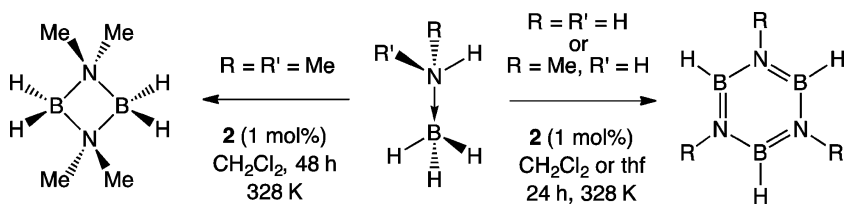

While the turnover frequencies for these catalytic processes $(\sim 4$ $\mathrm{h}^{-1}$ for $\mathrm{H}_{3} \mathrm{~B} \cdot \mathrm{NH}_{3}$ ) are modest in comparison to the most active transition metal catalysts, they do, to our knowledge, represent the first example of methylamine- or ammonia-borane dehydrogenation catalyzed by a main group FLP., 14

In order to probe potential dehydrocoupling mechanisms, attempts were made to monitor reactivity in situ by multinuclear NMR measurements and to examine the products of the stoichiometric reactions of $\mathbf{2}$ with ammonia- and amine-boranes at $295 \mathrm{~K}$. Revealingly, the 1:1 reactions of 2 with adducts of the general composition $\mathrm{H}_{3} \mathrm{~B} \cdot \mathrm{NMe}_{n} \mathrm{H}_{3-n}(n=0-3)$ all proceed via $\mathrm{B}-\mathrm{H}$ activation, generating a boron-bound hydride and a $\mathrm{P}$ $\mathrm{BH}_{2} \mathrm{NMe}_{n} \mathrm{H}_{3-n}$ unit (Scheme 3). All four structures were

Scheme 3. Stoichiometric Reactions of 2 with $\mathrm{H}_{3} \mathrm{~B} \cdot \mathrm{NMe}_{n} \mathrm{H}_{3-n}$ $(n=0-3)$ Proceeding via $\mathrm{B}-\mathrm{H}$ Bond Cleavage

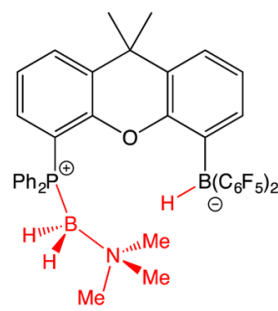

2-( $\mathrm{H})\left(\mathrm{BH}_{2} \mathrm{NMe}_{3}\right)$

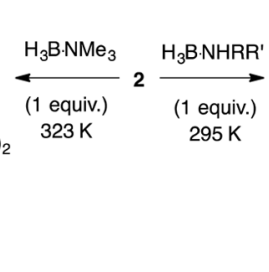

2-(H) $\left(\mathrm{BH}_{2} \mathrm{NH}_{3}\right): \mathrm{R}=\mathrm{R}^{\prime}=\mathrm{H}$ 2-(H) $\left(\mathrm{BH}_{2} \mathrm{NH}_{2} \mathrm{Me}\right): \mathrm{R}=\mathrm{H}, \mathrm{R}^{\prime}=\mathrm{Me}$ 2-(H) $\left(\mathrm{BH}_{2} \mathrm{NHMe}_{2}\right): \mathrm{R}=\mathrm{R}^{\prime}=\mathrm{Me}$ confirmed by X-ray crystallography (Figure 1 and SI), and in the case of 2-(H) $\left(\mathrm{BH}_{2} \mathrm{NH}_{3}\right), 2-(\mathrm{H})\left(\mathrm{BH}_{2} \mathrm{NH}_{2} \mathrm{Me}\right)$, and 2$(\mathrm{H})\left(\mathrm{BH}_{2} \mathrm{NHMe}_{2}\right)$, the existence of short $\mathrm{NH} \cdots \mathrm{HB}$ contacts $(\sim 1.9 \AA)$ involving the hydride of the $\left[\mathrm{ArB}\left(\mathrm{C}_{6} \mathrm{~F}_{5}\right)_{2} \mathrm{H}\right]^{-}$unit and a proton of the coordinated amine could be inferred from the difference Fourier maps. ${ }^{18}$

Spectroscopically, each of the $\mathrm{B}-\mathrm{H}$ activation products derived from 2 is characterized by a ${ }^{31} \mathrm{P}$ resonance in the range $1.7-6.3$ ppm and by ${ }^{11} \mathrm{~B}$ NMR signals at $\delta_{\mathrm{B}}-9.4$ to $-20.7 \mathrm{ppm}\left(\mathrm{PBH}_{2} \mathrm{~N}\right)$ and $\sim-21.5 \mathrm{ppm}$ (for the borohydride unit). With respect to chemistry occurring under catalytic conditions, the ${ }^{1} \mathrm{H},{ }^{11} \mathrm{~B}$, and ${ }^{31} \mathrm{P}$ resonances for 2-(H) $\left(\mathrm{BH}_{2} \mathrm{NH}_{3}\right), \mathbf{2}-(\mathrm{H})\left(\mathrm{BH}_{2} \mathrm{NH}_{2} \mathrm{Me}\right)$, and 2$(\mathrm{H})\left(\mathrm{BH}_{2} \mathrm{NHMe}_{2}\right)$ are found to correspond to the major species present in solution at short reaction times. In addition, isolated samples of these adducts are competent in the catalytic
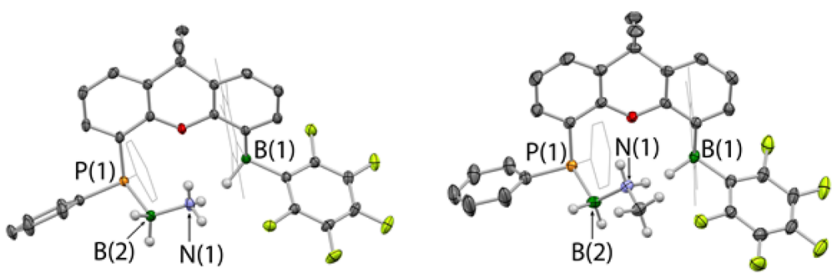

Figure 1. Structures of 2-(H) $\left(\mathrm{BH}_{2} \mathrm{NH}_{3}\right) \cdot \mathrm{CH}_{2} \mathrm{Cl}_{2}$ (left) and 2-(H)$\left(\mathrm{BH}_{2} \mathrm{NH}_{2} \mathrm{Me}\right)$ (right) as determined by X-ray cry-stallography. Here and elsewhere: Most $\mathrm{H}$ atoms and solvate molecule omitted, and selected aryl groups shown in wireframe format for clarity; thermal ellipsoids set at the $40 \%$ probability level. Key metrical parameters: (for 2- $(\mathrm{H})\left(\mathrm{BH}_{2} \mathrm{NH}_{3}\right)$. $\left.\mathrm{CH}_{2} \mathrm{Cl}_{2}\right) \quad \mathrm{P}(1) \cdots \mathrm{B}(1)$ 4.692(5) $\mathrm{P}(1)-\mathrm{B}(2)$ 1.952(4), $\mathrm{N}(1)-\mathrm{B}(2)$ 1.578(7) $\AA$; (for 2-(H) $\left(\mathrm{BH}_{2} \mathrm{NH}_{2} \mathrm{Me}\right)$ ) $\mathrm{P}(1) \cdots \mathrm{B}(1)$ 4.600(3), $\mathrm{P}(1)-$ $\mathrm{B}(2) 1.958(3), \mathrm{B}(2)-\mathrm{N}(1) 1.578(4) \AA$.

dehydrogenation of the corresponding ammonia- or amineborane, providing comparable performance to $\mathbf{2}$ itself under matching conditions. As such, it seems likely that these systems are viable intermediates in the respective catalytic dehydrocoupling processes.

Uhl and Slootweg have previously reported the synthesis of complexes featuring the $\mathrm{H}_{2} \mathrm{BNH}_{2}$ and $\mathrm{H}_{2} \mathrm{BNMe}_{2}$ fragments trapped by a phosphorus/aluminum FLP, ${ }^{9}$ and in the case of the dimethylaminoborane adduct showed that such a species is a potential intermediate in the dehydrocoupling of $\mathrm{H}_{3} \mathrm{~B} \cdot \mathrm{NHMe}_{2}$ to $\mathrm{H}_{2} \mathrm{~B}\left(\mu-\mathrm{NMe}_{2}\right)_{2} \mathrm{BH}_{2}$ in a melt. With this in mind, together with the close $\mathrm{NH} \cdots \mathrm{HB}$ contacts measured for 2- $(\mathrm{H})\left(\mathrm{BH}_{2} \mathrm{NH}_{3}\right)$, 2$(\mathrm{H})\left(\mathrm{BH}_{2} \mathrm{NH}_{2} \mathrm{Me}\right)$, and 2- $(\mathrm{H})\left(\mathrm{BH}_{2} \mathrm{NHMe}_{2}\right)$ in the solid state, we hypothesized that the loss of $\mathrm{H}_{2}$ from these systems might be relevant in a catalytic context. To our surprise, however, solutions of these adducts are inert to thermal loss of $\mathrm{H}_{2}$ in the temperature regime associated with the catalytic processes. Thus, e.g., 2$(\mathrm{H})\left(\mathrm{BH}_{2} \mathrm{NH}_{3}\right)$ remains unchanged in dichloromethane- $d_{2}$ after $24 \mathrm{~h}$ at $328 \mathrm{~K}$, as judged by in situ multinuclear NMR measurements. Dehydrogenation can be effected through the use of a hydrogen acceptor such as ${ }^{i} \mathrm{Pr}_{2} \mathrm{~N}=\mathrm{BH}_{2}$ (in a fashion similar to that demonstrated by Manners et al.), ${ }^{19}$ and the aminoborane product 2-( $\left.\mathrm{BH}_{2} \mathrm{NH}_{2}\right)$ characterized both spectroscopically and crystallographically (Scheme 4). However, it appears that this species is not relevant to the productive catalytic cycle: $2-\left(\mathrm{BH}_{2} \mathrm{NH}_{2}\right)$ is inert to further reaction with $\mathrm{AB}$ under

Scheme 4. Formation of the off-cycle Aminoborane Adduct $2-\left(\mathrm{BH}_{2} \mathrm{NH}_{2}\right)^{a}$

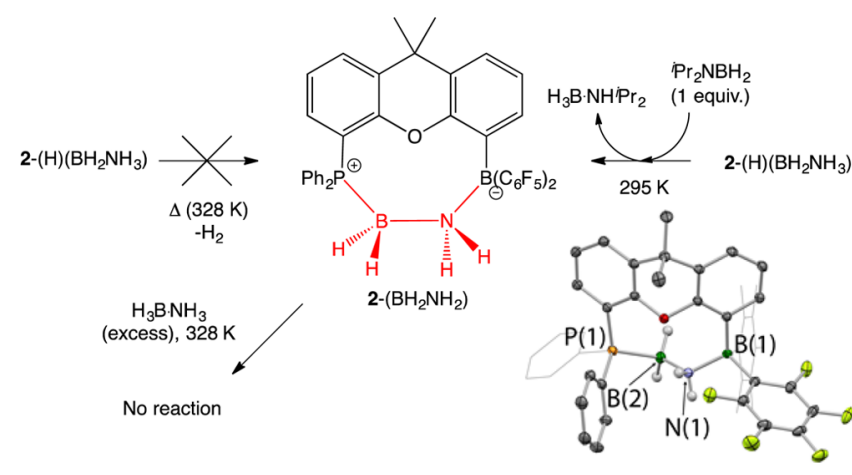

${ }^{a}$ Inset: structure of $2-\left(\mathrm{BH}_{2} \mathrm{NH}_{2}\right) \cdot \mathrm{CH}_{2} \mathrm{Cl}_{2}$ as determined by X-ray crystallography. Key metrical parameters: $\mathrm{P}(1) \cdots \mathrm{B}(1) 4.268(2), \mathrm{P}(1)-$ $\mathrm{B}(2) 1.968(2), \mathrm{B}(2)-\mathrm{N}(1) 1.612(3), \mathrm{N}(1)-\mathrm{B}(1)$ 1.582(3) $\mathrm{A}$. 
conditions identical to those used in catalytic runs, remaining unchanged over $24 \mathrm{~h}$ at $328 \mathrm{~K}$ in dichloromethane- $d_{2}$ solution.

The apparent inertness of isolated samples of $2-(\mathrm{H})\left(\mathrm{BH}_{2} \mathrm{NH}_{3}\right)$ and $2-(\mathrm{H})\left(\mathrm{BH}_{2} \mathrm{NH}_{2} \mathrm{Me}\right)$ toward thermal loss of $\mathrm{H}_{2}$ suggested that their onward reactivity might be dependent on the presence of additional ammonia- or amine-borane. In the case of the 2/ $\mathrm{H}_{3} \mathrm{~B} \cdot \mathrm{NH}_{3}$ catalytic runs, this hypothesis is also consistent with the observation of a second intermediate species, which can be shown (by comparison of multinuclear NMR data with the independently synthesized complex) to be the oligomeric borane adduct, 2$(\mathrm{H})\left(\mathrm{BH}_{2} \mathrm{NH}_{2} \mathrm{BH}_{2} \mathrm{NH}_{3}\right)$ (SI and Figure 2, left). Although labile in

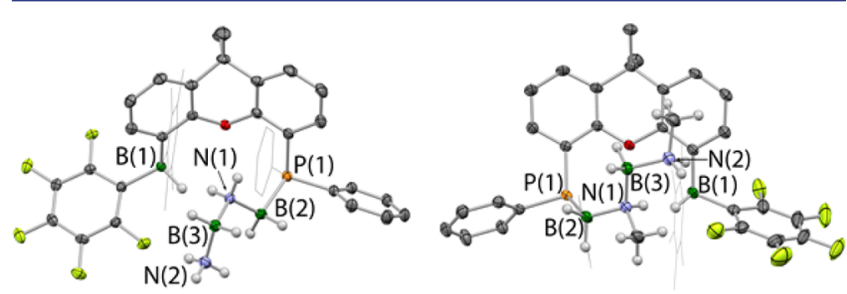

Figure 2. Structures of 2- $(\mathrm{H})\left(\mathrm{BH}_{2} \mathrm{NH}_{2} \mathrm{BH}_{2} \mathrm{NH}_{3}\right)$ (left) and 2$(\mathrm{H})\left(\mathrm{BH}_{2} \mathrm{NHMeBH}_{2} \mathrm{NH}_{2} \mathrm{Me}\right)$ (right) as determined by X-ray crystallography. Key metrical parameters: (for 2-(H) $\left(\mathrm{BH}_{2}-\mathrm{NH}_{2} \mathrm{BH}_{2} \mathrm{NH}_{3}\right)$ ) $\mathrm{P}(1) \cdots \mathrm{B}(1)$ 4.690(3), $\mathrm{P}(1)-\mathrm{B}(2)$ 1.964(3), B(2)-N(1) 1.558(3), $\mathrm{N}(1)-\mathrm{B}(3) \quad 1.575(3), \mathrm{B}(3)-\mathrm{N}(2)$ 1.587(3) $\AA$; (for 2-(H)$\left(\mathrm{BHNHMeBH} \mathrm{NH}_{2} \mathrm{Me}\right)$ ) $\mathrm{P}(1)-\mathrm{B}(1)$ 4.668(4), $\mathrm{P}(1)-\mathrm{B}(2)$ 1.969(5), $\mathrm{B}(2)-\mathrm{N}(1)$ 1.562(5), N(1)-B(3) 1.567(5), B(3)-N(2) 1.604(5).

dichloromethane solution at $295 \mathrm{~K}$, this compound can be obtained as a compositionally pure material via the alternative reaction of 2 with $\mathrm{H}_{3} \mathrm{~B} \cdot \mathrm{NH}_{2} \mathrm{BH}_{2} \cdot \mathrm{NH}_{3}$ and crystallized from $\mathrm{CH}_{2} \mathrm{Cl}_{2} /$ hexane at $273 \mathrm{~K}$. Structurally, 2 $(\mathrm{H})\left(\mathrm{BH}_{2} \mathrm{NH}_{2} \mathrm{BH}_{2} \mathrm{NH}_{3}\right)$ (in common with 2-(H) $\left(\mathrm{BH}_{2} \mathrm{NH}_{3}\right)$ ) features an P-bound aminoborane chain which is additionally "anchored" at the $\beta$-N position through an $\mathrm{NH} \cdot \cdots \mathrm{HB}$ interaction with the borohydride group $(\sim 1.91 \AA)$.

While the lability of 2 - $(\mathrm{H})\left(\mathrm{BH}_{2} \mathrm{NH}_{2} \mathrm{BH}_{2} \mathrm{NH}_{3}\right)$ prevents meaningful attempts to study its onward reactivity, the corresponding product derived from $\mathrm{H}_{3} \mathrm{~B} \cdot \mathrm{NHMeBH} \mathrm{H}_{2} \cdot \mathrm{NH}_{2} \mathrm{Me}$ by terminal $\mathrm{B}-\mathrm{H}$ activation is stable in dichloromethane solution at $295 \mathrm{~K}$ over a period of $24 \mathrm{~h}$ and can therefore be used to probe potential mechanistic pathways (Scheme 5 and Figure 2). Moreover, while 2- $(\mathrm{H})\left(\mathrm{BH}_{2} \mathrm{NHMeBH}_{2} \mathrm{NH}_{2} \mathrm{Me}\right)$ is most conveniently accessed for synthetic purposes from the preformed $\mathrm{BNBN}$ oligomer, it is also the product of the reaction of 2$(\mathrm{H})\left(\mathrm{BH}_{2} \mathrm{NH}_{2} \mathrm{Me}\right)$ with a second equivalent of $\mathrm{H}_{3} \mathrm{~B} \cdot \mathrm{NHMe}_{2}$ ( $50 \%$ conversion over a period of $2 \mathrm{~h}$ at $328 \mathrm{~K}$ in dichloromethane), thereby providing evidence for a dehydrogenative chain-growth process. ${ }^{20}$ In addition, the reaction of 2 - $(\mathrm{H})$ $\left(\mathrm{BH}_{2} \mathrm{NHMeBH}_{2} \mathrm{NH}_{2} \mathrm{Me}\right)$ itself with a further equivalent of $\mathrm{H}_{3} \mathrm{~B}$. $\mathrm{NH}_{2} \mathrm{Me}$ generates the (known) cyclic trimer $\left(\mathrm{H}_{2} \mathrm{BNHMe}\right)_{3}$ as the major product, along with small amount of trimethylborazine. This cyclic trinuclear borazane can also be identified in $2 / \mathrm{H}_{3} \mathrm{~B}$. $\mathrm{NH}_{2} \mathrm{Me}$ catalytic runs by in situ multinuclear NMR spectroscopy (Figure S3). These stoichiometric reactivity studies suggest that a viable reaction pathway under catalytic conditions involves the stepwise assimilation of two $\mathrm{BN}$-containing units to give 2$(\mathrm{H})\left(\mathrm{BH}_{2} \mathrm{NHMeBH}_{2} \mathrm{NH}_{2} \mathrm{Me}\right)$, followed by uptake of a third molecule of the amine-borane and ejection of cyclic $\left(\mathrm{H}_{2} \mathrm{BNHMe}\right)_{3}$. The loss of the cyclic borazane via "backbiting" is presumably very rapid, as no spectroscopic evidence is obtained for the preceding P-BNBNBN linear chain. However, consistent with its role as an intermediate in the overall dehydrogenation of
Scheme 5. Stepwise Growth of the Oligomeric Aminoborane Chain by Sequential Uptake of $\mathrm{H}_{3} \mathrm{~B} \cdot \mathrm{NH}_{2} \mathrm{Me}$ Monomer

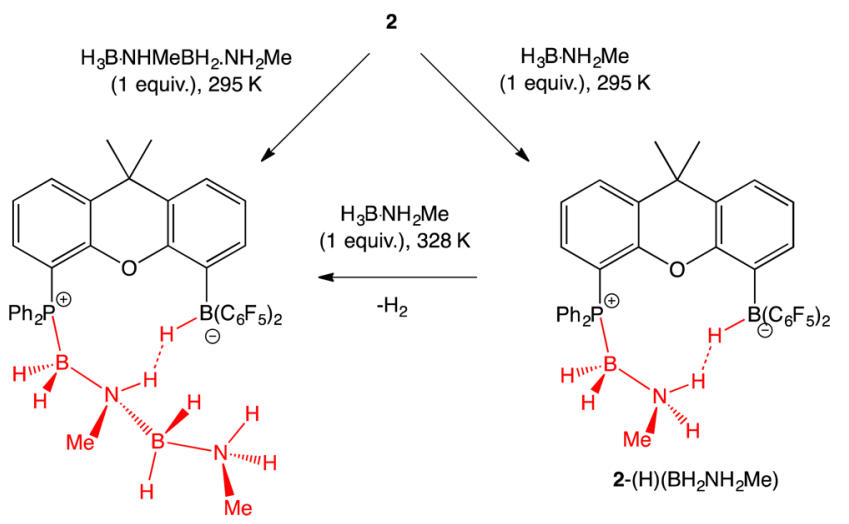

2-(H) $\left(\mathrm{BH}_{2} \mathrm{NHMeBH}_{2} \mathrm{NH}_{2} \mathrm{Me}\right)$

$\mathrm{H}_{3} \mathrm{~B} \cdot \mathrm{NH}_{2} \mathrm{Me}$

(1 equiv.), $295 \mathrm{~K}$

$\checkmark \quad-2 \mathrm{H}_{2}$
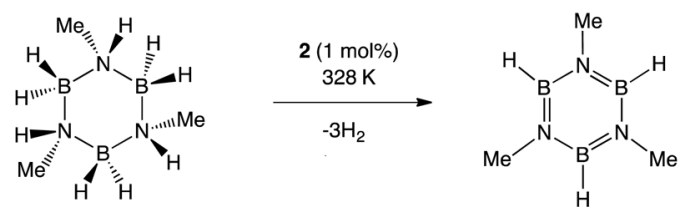

$\mathrm{H}_{3} \mathrm{~B} \cdot \mathrm{NH}_{2} \mathrm{Me}$ to trimethylborazine, cyclo- $\left(\mathrm{H}_{2} \mathrm{BNHMe}\right)_{3}$ can be synthesized independently ${ }^{21}$ and is shown to undergo further dehydrogenation under catalytic conditions $\left(\mathrm{CH}_{2} \mathrm{Cl}_{2}\right.$ solution, $328 \mathrm{~K}$, using $1 \mathrm{~mol} \% 2$ ) to generate the final trimethylborazine product over a period of time $(24 \mathrm{~h})$ consistent with its competence as a catalytic intermediate.

While the evolution of dihydrogen in both the $2 / \mathrm{H}_{3} \mathrm{~B} \cdot \mathrm{NH}_{3}$ and $2 / \mathrm{H}_{3} \mathrm{~B} \cdot \mathrm{NH}_{2} \mathrm{Me}$ catalytic systems can be shown explicitly by ${ }^{1} \mathrm{H}$ NMR, the unfavorable equilibrium for the capture of $\mathrm{H}_{2}$ by 2 means that 2- $(\mathrm{H})_{2}$ does not build up to sufficient concentrations and that it can be identified in situ, even at the end of catalytic runs. Instead, the major FLP-containing species present when all of the substrate has been consumed can be identified as the respective Bbound amine adducts $2-\mathrm{NH}_{2} \mathrm{R}(\mathrm{R}=\mathrm{H}$ or $\mathrm{Me})$, by comparison with the products obtained from the corresponding Lewis acid/ base reactions of 2 with $\mathrm{NH}_{3}$ or $\mathrm{MeNH}_{2}$.

With a view to probing in more depth the mechanism by which growth of the $\mathrm{BN}$ oligomeric chain occurs, the reaction between 2- $(\mathrm{H})\left(\mathrm{BH}_{2} \mathrm{NHMe}_{2}\right)$ and $\mathrm{H}_{3} \mathrm{~B} \cdot \mathrm{NH}_{2} \mathrm{Me}$ was investigated (SI, Scheme S7). Although this reaction is kinetically slow, in situ NMR measurements indicate that the incoming methylamineborane unit is assimilated in a manner consistent with an endgrowth dehydrogenative coupling mechanism, rather than via insertion into the $\mathrm{P}-\mathrm{B}$ bond of $2-(\mathrm{H})\left(\mathrm{BH}_{2} \mathrm{NHMe}_{2}\right)$. The formation of the PBNBN backbone in the product is consistent with the appearance of ${ }^{11} \mathrm{~B}$ signals at $\delta_{\mathrm{B}}=-12.6$ and -6.4 (cf. $\delta_{\mathrm{B}}=$ -13.8 and -4.6 for the corresponding $\mathrm{PBN}$ and $\mathrm{NBN}$ units in 2$\left.(\mathrm{H})\left(\mathrm{BH}_{2} \mathrm{NHMeBH}_{2} \mathrm{NH}_{2} \mathrm{Me}\right)\right)$. Most informatively, the ${ }^{1} \mathrm{H}$ resonance associated with the terminal $\mathrm{N}$-bound methyl group in 2-( $\mathrm{H})\left(\mathrm{BH}_{2} \mathrm{NMe}_{2} \mathrm{BH}_{2} \mathrm{NH}_{2} \mathrm{Me}\right)$ is a 1:2:1 triplet of intensity three at $\delta_{\mathrm{H}}=2.24\left({ }^{3} \mathrm{~J}_{\mathrm{HH}}=5.6 \mathrm{~Hz}\right.$; cf. $\delta_{\mathrm{H}}=2.22$ for the $\mathrm{NH}_{2} \mathrm{Me}$ unit in 2-(H) $\left.\left(\mathrm{BH}_{2} \mathrm{NHMeBH}_{2} \mathrm{NH}_{2} \mathrm{Me}\right)\right)$, consistent with the presence of a capping $\mathrm{NH}_{2} \mathrm{Me}$ group (rather than $\mathrm{NMe}_{2} \mathrm{H}$ ).

In conclusion, we have demonstrated the catalytic dehydrogenation of ammonia- and amine-boranes by a FLP based on a preorganized dimethylxanthene backbone. This chemistry is 
initiated by $\mathrm{B}-\mathrm{H}$ activation, followed by end-growth $\mathrm{BN}$ coupling involving the terminal $\mathrm{NH}$ bond of the bound $\mathrm{BN}$ fragment and a $\mathrm{BH}$ bond of the incoming borane monomer. The propensity for competing intramolecular $\mathrm{H}_{2}$ loss at this stage appears to be minimal: independent synthesis of the $\mathrm{P}-\mathrm{BH}_{2} \mathrm{NH}_{2}-\mathrm{B}$ aminoborane complex allows us to demonstrate that it is not a viable catalytic intermediate and that it is not formed in detectable amounts as a side-product. The reluctance of the system to lose $\mathrm{H}_{2}$ intramolecularly potentially reflects the very strong $\mathrm{B}-\mathrm{H}$ bond to the electron-deficient $\mathrm{BAr}\left(\mathrm{C}_{6} \mathrm{~F}_{5}\right)_{2}$ unit. Alternative intermolecular loss of $\mathrm{H}_{2}$ at this stage to generate a P-bound BNBN linear oligomer can be demonstrated explicitly for methylamine-borane. Nonetheless, this is the only step in the stoichiometric formation of the cyclic triborazane $\left(\mathrm{H}_{2} \mathrm{BNHMe}\right)_{3}$ from $\mathrm{H}_{3} \mathrm{~B} \cdot \mathrm{NH}_{2} \mathrm{Me}$, e.g., which does not occur spontaneously at room temperature (requiring heating to $328 \mathrm{~K}$ ). As such, it seems plausible that under catalytic conditions this might be the rate-limiting step. ${ }^{22}$ That the assimilation of the second $\mathrm{BN}$ unit appears to be slower than the subsequent uptake of the third equivalent of amineborane potentially reflects greater steric shrouding of the terminal $\mathrm{N}-\mathrm{H}$ bond in species such as $2-(\mathrm{H})\left(\mathrm{BH}_{2} \mathrm{NH}_{2} \mathrm{Me}\right)$ than in its longer chain analogue 2-(H) $\left(\mathrm{BH}_{2} \mathrm{NHMeBH}_{2} \mathrm{NH}_{2} \mathrm{Me}\right)$.

\section{ASSOCIATED CONTENT}

\section{S Supporting Information}

The Supporting Information is available free of charge on the ACS Publications website at DOI: 10.1021/jacs.6b01170.

Experimental details and data (PDF)

Crystallographic data (CIF)

\section{AUTHOR INFORMATION}

\section{Corresponding Author}

*simon.aldridge@chem.ox.ac.uk

\section{Notes}

The authors declare no competing financial interest.

\section{ACKNOWLEDGMENTS}

EPSRC (EP/K503769/1, EP/K014714/1); EU Marie Curie (E.L.K., A.R.: grants PIEF-GA-2013-626441 and PIEF-GA-2013622806).

\section{REFERENCES}

(1) (a) Hansmann, M. M.; Melen, R. L.; Wright, D. W. Chem. Sci. 2011, 2, 1554. (b) Leitao, E. M.; Jurca, T.; Manners, I. Nat. Chem. 2013, 5, 817. (c) Waterman, R. Chem. Soc. Rev. 2013, 42, 5629.

(2) (a) Staubitz, A.; Robertson, A. P. M.; Sloan, M. E.; Manners, I. Chem. Rev. 2010, 110, 4023. (b) Staubitz, A.; Robertson, A. P. M.; Manners, I. Chem. Rev. 2010, 110, 4079.

(3) Stephens, F. H.; Pons, V.; Baker, R. T. Dalton Trans. 2007, 2613.

(4) For an early report see: Jaska, C. A.; Temple, K.; Lough, A. J.; Manners, I. J. Am. Chem. Soc. 2003, 125, 9424.

(5) (a) Marder, T. B. Angew. Chem., Int. Ed. 2007, 46, 8116. (b) Pons, V.; Baker, R. T. Angew. Chem., Int. Ed. 2008, 47, 9600.

(6) For an early report of ionic liquids to accelerate $A B$ dehydrogenation see: Bluhm, M. E.; Bradley, M. G.; Butterick, R., III; Kusari, U.; Sneddon, L. G. J. Am. Chem. Soc. 2006, 128, 7748.

(7) For an early report of acid catalysis of $A B$ dehydrogenation see: (a) Stephens, F. H.; Baker, R. T.; Matus, M. H.; Grant, D. J.; Dixon, D. A. Angew. Chem., Int. Ed. 2007, 46, 746. For a recent example of a similar process effected by a bifunctional borane see: Lu, Z.; Schweighauser, L.; Hausmann, H.; Wegner, A. Angew. Chem., Int. Ed. 2015, 54, 15556.

(8) Lewis base catalyzed $\mathrm{AB}$ dehydrogenation: Himmelberger, D. W.; WonYoon, C.; Bluhm, M. E.; Carroll, P. J.; Sneddon, L. G. J. Am. Chem. Soc. 2009, 131, 14101.
(9) Uhl, Slootweg et al. have reported the dehydrocoupling of $\mathrm{H}_{3} \mathrm{~B}$. $\mathrm{NHMe}_{2}$ to $\mathrm{H}_{2} \mathrm{~B}\left(\mu-\mathrm{NMe}_{2}\right)_{2} \mathrm{BH}_{2}$ in a melt $(363 \mathrm{~K})$ catalysed by a P/Al FLP ( $9.3 \mathrm{~mol} \%$ ), although this system does not dehydrocouple $\mathrm{H}_{3} \mathrm{~B} \cdot \mathrm{NH}_{3}$ or $\mathrm{H}_{3} \mathrm{~B} \cdot \mathrm{NH}_{2} \mathrm{Me}$ : (a) Appelt, C.; Slootweg, J. C.; Lammertsma, K.; Uhl, W. Angew. Chem., Int. Ed. 2013, 52, 4256. See also: (b) Alexander, J. M.; Bercaw, J. E. Chem. Commun. 2010, 46, 1709. (c) Whittell, G. R.; Balmond, E. I.; Robertson, A. P. M.; Patra, S. K.; Haddow, N.; Manners, I. Eur. J. Inorg. Chem. 2010, 2010, 3967.

(10) Brown, H. C.; Schlesinger, H. I.; Cardon, S. Z. J. Am. Chem. Soc. $1942,64,325$

(11) Welch, G. C.; Juan, R. R. S.; Masuda, J. D.; Stephan, D. W. Science 2006, 314, 1124 .

(12) For recent reviews see: (a) Stephan, D. W.; Erker, G. Angew. Chem., Int. Ed. 2010, 49, 46. (b) Stephan, D. W.; Greenberg, S.; Graham, T. W.; Chase, P.; Hastie, J. J.; Geier, S. J.; Farrell, J. M.; Brown, C. C.; Heiden, Z. M.; Welch, G. C.; Ullrich, M. Inorg. Chem. 2011, 50, 12338. (c) Erker, G. Dalton Trans. 2011, 40, 7475. (e) Stephan, D. W. Org. Biomol. Chem. 2012, 10, 5740. (f) Stephan, D. W.; Erker, G. Angew. Chem., Int. Ed. 2015, 54, 6400. (g) Stephan, D. W. Acc. Chem. Res. 2015, 48, 306. (h) Stephan, D. W. J. Am. Chem. Soc. 2015, 137, 10018.

(13) For an early report of FLP-catalysed hydrogenation see: (a) Chase, P. A.; Welch, G. C.; Jurca, T.; Stephan, D. W. Angew. Chem., Int. Ed. 2007, 46, 8050. (b) Spies, P.; Schwendemann, S.; Lange, S.; Kehr, G.; Froehlich, R; Erker, G. Angew. Chem., Int. Ed. 2008, 47, 7543. For a review of related hydrosilylation chemistry see: (c) Piers, W. E.; Marwitz, A.J. V.; Mercier, L. G. Inorg. Chem. 2011, 50, 12252.

(14) FLPs incorporating transition metals also mediate BN dehydrocoupling: Chapman, A. M.; Haddow, M. F.; Wass, D. F. J. Am. Chem. Soc. 2011, 133, 18463.

(15) For selected examples of FLPs capable of the activation of $\mathrm{H}_{2}$ and release under vacuum see ref 11 and (a) Wang, H.; Fröhlich, R.; Kehr, G.; Erker, G. Chem. Commun. 2008, 5966. (b) Sumerin, V.; Schulz, F.; Atsumi, M.; Wang, C.; Nieger, M.; Leskelä, M.; Repo, T.; Pyykkö, P.; Rieger, B. J. Am. Chem. Soc. 2008, 130, 14117. (c) Sumerin, V.; Schilz, F.; Nieger, M.; Leskelä, M.; Repo, T.; Rieger, B. Angew. Chem., Int. Ed. 2008, 47, 6001. (d) Ullrich, M.; Lough, A. J.; Stephan, D. W. J. Am. Chem. Soc. 2009, 131, 52. (e) Schwendemann, S.; Fröhlich, R.; Kehr, G.; Erker, G. Chem. Sci. 2011, 2, 1842. (f) Sumerin, V.; Chernichenko, K.; Nieger, M.; Leskelä, M.; Rieger, B.; Repo, T. Adv. Synth. Catal. 2011, 353, 2093. (g) Jiang, C.; Blacque, O.; Fox, T.; Berke, H. Dalton Trans. 2011, 40, 1091. (h) Chernichenko, K.; Nieger, M.; Leskelä, M.; Repo, T. Dalton Trans. 2012, 41, 9029. (i) Binding, S. C.; Zaher, H.; Chadwick, F. M.; O'Hare, D. Dalton Trans. 2012, 41, 9061. Weaker acid/base combinations have also been reported which cleave dihydrogen in solution at low temperatures and/or elevated pressures, which quantitatively evolve $\mathrm{H}_{2}$ on warming to room temperature: $(j)$ Greb, L.; Oña-Burgos, P.; Shirmer, B.; Grimme, S.; Stephan, D. W.; Paradies, J. Angew. Chem., Int. Ed. 2012, 51, 10164. (k) Greb, L.; Tussing, S.; Schirmer, B.; Oña-Burgos, P.; Kaupmees, K.; Lõkov, M.; Leito, I.; Grimme, S.; Paradies, J. Chem. Sci. 2013, 4, 2788. (1) Chernichenko, K.; Kótai, B.; Pápai, I.; Zhivonitko, V.; Nieger, M.; Leskelä, M.; Repo, T. Angew. Chem., Int. Ed. 2015, 54, 1749.

(16) Mo, Z.; Kolychev, E. L.; Rit, A.; Campos, J.; Niu, H.; Aldridge, S. J. Am. Chem. Soc. 2015, 137, 12227.

(17) (a) Rokob, T. A.; Hamza, A.; Pápai, I. J. Am. Chem. Soc. 2009, 131, 10701. (b) Neu, R.; Ouyang, E. Y.; Geier, S. J.; Zhao, X.; Ramos, A.; Stephan, D. W. Dalton Trans. 2010, 39, 4285.

(18) Schulz, F.; Sumerin, V.; Heikkinen, S.; Pedersen, B.; Wang, C.; Atsumi, M.; Leskelä, M.; Repo, T.; Pyykkö, P.; Petry, W.; Rieger, B. J.Am. Chem. Soc. 2011, 133, 20245.

(19) Leitao, E. M.; Stubbs, N. E.; Robertson, A. P. M.; Helten, H.; Cox, R. J.; Lloyd-Jones, G. C.; Manners, I. J. Am. Chem. Soc. 2012, 134, 16805.

(20) Johnson, H. C.; Robertson, A. P. M.; Chaplin, A. B.; Sewell, L. J.; Thompson, A. L.; Haddow, M. F.; Manners, I.; Weller, A. S. J. Am. Chem. Soc. 2011, 133, 11076.

(21) Framery, E.; Vaultier, M. Heteroat. Chem. 2000, 11, 218.

(22) The reduced reaction rates in catalytic runs using $\mathrm{D}_{3} \mathrm{~B} \cdot \mathrm{NH}_{2} \mathrm{Me}$ $\left(k_{\mathrm{H}} / k_{\mathrm{D}}=3.9\right)$ and $\mathrm{H}_{3} \mathrm{~B} \cdot \mathrm{ND}_{2} \mathrm{Me}\left(k_{\mathrm{H}} / k_{\mathrm{D}}=2.9\right)$ are consistent with a ratelimiting step involving the breakage of both $\mathrm{B}-\mathrm{H}$ and $\mathrm{N}-\mathrm{H}$ bonds (SI). 